\title{
The Integration of Network Teaching and Chinese Art History Education in Colleges
}

\author{
Tiantian Hou* \\ Xianyang Normal University, Xianyang 712000, Shaanxi Province, China
}

\begin{abstract}
Based on the network teaching model, this article briefly summarizes the development of Chinese art history education in universities, analyzes the importance of integrating network teaching in Chinese art history lessons, and explores the integration strategy.
\end{abstract}

Keywords: Network teaching model; Colleges and universities; Chinese art history teaching; Integration strategy

Publication date: May, 2021; Publication online: 31 May, 2021

*Corresponding author: Tiantian Hou, tiantian19930103@sina.com

\section{Introduction}

In the education of Chinese art history, visual arts are very important. Students usually have relatively strong art aesthetic and visual color analysis abilities. However, traditional art education in colleges and universities usually practices passive learning. Students accept this learning method which results in a neglect of the most important aspect of art education which is aesthetics and visual sense. This can be solved by applying modern technology network to art education in colleges and universities. Teachers can use multimedia to improve educational contents, thereby enriching the teaching environment, heighten the quality of education, and aiding students to promote their visualizing skills.

\section{Development of Chinese Art History} Education in Colleges and Universities

\subsection{Old textbook versions}

In assessing students, grades are given based on answering a few questions from textbooks. However, these textbooks have not been updated for a long time, hence, failing to meet the developmental needs of students. On the other hand, modern technology develops rapidly, and new information often replaces the old. University education should include a wide range of subjects including general education and humanities in addition to their main education in order for students to adapt to the society. The practice of using specific textbooks or using multiple textbooks is still controversial. Hence, some universities are restricted by certain conditions. It is found that many universities are still using the "Outline of Chinese Art History" textbook which was published in 1993 as the designated textbook for their art history courses. ${ }^{[1]}$ The teaching practices and scientific research of art history are constantly developing with substantial amount of new information. Hence, the results of many scientific research have replaced existing views. It is recommended to update or use different textbooks and develop network resources so that students can truly learn "art."

\subsection{A one-way teaching method}

At present, the method of teaching art history in a few colleges uses the one-way teaching method which is a reflection of how history subjects are taught in elementary and high school. The issues are the lack of interaction between teachers and students, and the failure to motivate students. Other than that, due to narrow understanding of art history and limited textbook knowledge among students, it is a consideration for universities to re-evaluate its 
education system in regard to restricting "syllabus" and limiting the scope of the examination. A diverse and engaging classroom environment should be created. Technology networks can also be used to promote classroom discussions and research in education.

\subsection{Insufficient educational resources}

The problem of the current art history education is not about the shortage of talents, but about selecting and consolidating resources. In addition to textbooks and reference books, there are various other educational resources. Network resources are indispensable, and they are important forms of educational resources. For teachers, using the Internet to teach and obtain materials are important skills. However, students face uncertainties in choosing online materials or reference books from a large number of resources when teachers do not guide or recommend them. Therefore, teachers should guide their students in addition to their roles as teachers. In the education of Chinese art history, teachers should try to use representative works or examples in their lessons while encouraging students to apply what they have learned in order to analyze cases in different situations.

\section{Importance of Integrating Online Teaching and Chinese Art History Education in Colleges}

In traditional Chinese art history courses, teachers teach their students to appreciate artwork by analyzing pictures shown in textbooks. The context of appreciation is relatively simple; however, the students' knowledge of art theory is limited. Therefore, the teaching of traditional Chinese art history courses is relatively boring for students. Abundant educational resources which are rapidly accessible and the use of detailed statistical data in online education have improved students' cognition and improved their cognitive processing. This student-centered and teacher-led method will benefit in the teaching process based on students' abilities. The integration of online teaching and Chinese art history education in colleges and universities helps to increase students' interest in learning. The online education content can be another teaching method of Chinese art history which helps students gain knowledge in various aspects while creating fun and diversity in classroom lessons. ${ }^{[2]}$ This integration is conducive in fostering innovation that is needed by the current society. In this information age, access to vast amount of knowledge has become more convenient. In regard to this, students must learn to gather and organize information by determining its' authenticity and looking at problems dialectically. This would also promote students' comprehensive and independent learning skills. In an offline teaching method, a generative learning can only be optimized through reflections after classes. However, the outcomes of a lesson via online method can be directly assessed through activities. The integration the online method also improves classroom efficiency and helps students to develop self-study habits. In flipped classrooms, homework is arranged in advance, and questions are given beforehand to develop the habit of self-study. A clear goal-based teaching enables students to identify learning goals and course content which greatly improves the efficiency of classroom learning.

\section{Strategies for Integrating Online Teaching and Chinese Art History Education in Colleges \\ 4.1 Technology network in enriching content and value of textbooks}

By using technology network, the content and value of art history textbooks may be enriched. This method not only provides textbook knowledge, but it also meets the learning requirements and maximizes the students' abilities in addition to cultivating students' interest. The introduction of multimedia technology into the art education of universities also provides many visual materials and experiences that combine sounds and artworks, all of which are helpful to students' learning and art skills. Currently, the role of technology network is to help students expand the value of classroom teaching by enriching the content of textbooks. In traditional art lessons, teachers often bring photo albums or allow students to look for related photos in the reference rooms for explanations and 
analyses when questions arise. However, with the help of technology network, teachers and students may easily access relevant photos and other materials, hence, avoiding errors, solving problems in short periods, and improving the quality and effectiveness of professors. ${ }^{[4]}$

\subsection{Technology network in enriching teaching resources}

The university's Chinese Art History course is a compulsory course for art students. The purpose of this education is to help students appreciate artworks by analyzing and understanding the perceived emotions in an art piece. The ability to appreciate artworks will eventually train students to see the world through the eyes of the artist. Therefore, university teachers can incorporate high-quality online educational materials into the research of Chinese art history, so that students will be able to gather more knowledge. Learning tasks can also be pre-assigned to students for them to study in an orderly manner. For example, to learn about landscape paintings in the Northern Song Dynasty, teachers can look for high-quality educational videos that explains the development of that dynasty and share them with the students. This would help students understand the political, economic and cultural development of the Northern Song Dynasty. This course combines the historical aspects with the appreciation of artworks and helps students understand their relationship from different perspectives. Hence, by combining historical and aesthetic aspects, students will be able to appreciate the artworks dialectically. Learning via collecting network resources and filtering will help to improve dialectical thinking skills. The foundation of Chinese paintings is the basic idea in art history education. The integration of painting skills into Chinese art history education through online resources not only engages students, but also enables students to learn painting skills. ${ }^{[3]}$

\subsection{Technology network in integrating education evaluations}

By using technology network, feedback on educational achievements and students' academic performances can be provided in a convenient and timely manner. Evaluation is important for teachers to prepare for the next lesson. To help students identify and solve problems, it requires substantial amount of time. Therefore, if accurate and comprehensive education evaluations can be obtained in time, it will be of great help to the education system. The rapid dissemination of information and detailed statistical data of the network platform may easily solve problems for the traditional teaching method. Completion of assignments can be checked via detailed statistics, reminders can be sent, tasks can be assigned in advance and even group discussions can be done on the online platform. This improves students' interactions and teamwork, stimulates their interest in learning, and helps to cultivate independent learning as well as creativity skills. Finally, using the network platform, multi-angle and mutual group evaluations can be done.

\section{Summary}

In conclusion, the traditional art education model is relatively backward. The passive teaching method neglects art visual education. However, the art history course is no longer a purely theoretical course. It emphasizes on students' aesthetics and creativity by combining the knowledge of art subjects with humanism. Through the integration of online education and Chinese art history education, it will improve the traditional education model, innovate teaching strategies, and motivate students to learn. This article promotes the development of Chinese art history education by using technology network to enrich the content and value of art history textbooks, teaching resources, and for educational evaluations and integration.

\section{Disclosure statement}

No conflicts of interest.

\section{References}

[1]Chen, C(2020). The integration of online teaching and Chinese art history teaching in colleges and universities. Art Grand View, (13): 
72-73.

[2] Qi, X(2018). A Discussion on the Teaching Ideas of "Chinese Art History" Course for Art Majors in Colleges and Universities. Journal of Yulin Teachers College, 39(01): 139-142, 147.

[3] Liu, E(2015). Research on Strategies to Improve the Effectiveness of Classroom Teaching of
Chinese Art History in Colleges and Universities. Journal of Liupanshui Teachers College, 27(05): 77-79.

[4] Song, X(2014). Reflections on the teaching of contemporary art history-Taking the teaching of "Chinese Art History" as an example. Yalu River, (04): 256. 